\title{
Determination of food sources for benthic invertebrates in a salt marsh (Aiguillon Bay, France) by carbon and nitrogen stable isotopes: importance of locally produced sources
}

\author{
P. Riera ${ }^{1,4, *}$, L. J. Stal ${ }^{1}$, J. Nieuwenhuize ${ }^{1}$, P. Richard ${ }^{2}$, G. Blanchard ${ }^{2,3}$, F. Gentil ${ }^{4}$ \\ ${ }^{1}$ Centre for Estuarine and Coastal Ecology, Netherlands Institute of Ecology (NIOO-CEMO), Postbus 140, 4400 AC Yerseke, \\ The Netherlands \\ ${ }^{2}$ Centre de Recherche en Écologie Marine et Aquaculture de L'Houmeau, UMR 10, CNRS-IFREMER, BP 5, Place du \\ Séminaire, 17137 L'Houmeau, France \\ ${ }^{3}$ Université de La Rochelle, LBBM, Pôle Science et Technologie, Avenue Marillac, 17042 La Rochelle cedex, France \\ ${ }^{4}$ Station Biologique de Roscoff, Université Pierre \& Marie Curie, CNRS UPR 9042, Place Georges-Teissier, BP 74, \\ 29682 Roscoff cedex, France
}

\begin{abstract}
C}$ and $\delta^{15} \mathrm{~N}$ were measured in benthic invertebrates and food sources collected in the salt marsh of the Aiguillon Bay, France. The results showed that, although Spartina anglica was dominant, this marine phanerogame did not contribute significantly to the carbon and nitrogen requirements of the invertebrates considered in this study In fact, Macoma balthica, Scrobicularia plana and Mytilus edulis preferentially fed on a mixture of benthic diatoms and marine phytoplankton, but in different proportions, as was estimated through isotope mixing models. However, this isotopic data set revealed complex trophic relationships for the nematode community and for the crab Carcinus maenas which did not allow accurate isotopic determination of food sources.
\end{abstract}

KEY WORDS: Carbon and nitrogen isotope ratios - Muddy salt marsh - Spartina anglica - Benthic diatoms - Benthic invertebrates

Coastal environments are generally characterised by a large number of locally produced and allochthonous potential food sources for benthic consumers. The diversity in origin of organic matter makes it difficult to determine which are the most important food sources and to quantitatively estimate their proportions in animal diets. The different food sources contribute to an important detrital organic matter pool (Pocklington \& Tan 1987, Mann 1988), and may be used differently by

\footnotetext{
-Address for correspondence: Station Biologique de Roscoff Place Georges-Teissier, BP 74, 29682 Roscoff cedex, France. E-mail: riera@sb-roscoff.fr
}

different animals due to their digestibility or because of hydrology that influences their production and availability to consumers (Schwinghamer et al. 1983, Monbet 1992). For example, in salt marshes vascular plants are less digestible than organic matter derived from algae, but may be used as a food source when they are decomposed by bacteria (Tenore 1983, Newell \& Langdon 1986, Mann 1988)

The analysis of stable isotope ratios of carbon and nitrogen of particulate organic matter (POM) in coastal environments has received increasing interest. This method allows the determination of different sources of organic matter in the POM pool and its exchange due to trophic interactions (Fry \& Sherr 1984, Deegan et al. 1990). A recent study, using stable isotopes ratios, has pointed out the preferential utilisation of local organic matter sources by benthic invertebrates in coastal marshes (Deegan \& Garritt 1997). However, allochthonous organic matter may increase the number of sources that can be used by local invertebrates. Particularly in estuarine habitats, significant incorporation of terrestrial organic matter by bivalve molluscs may occur in upper estuarine reaches or during a period of high freshwater discharge (lncze et al. 1982, Riera \& Richard 1996). Once the main food sources of a consumer have been identified, a quantitative assessment of the proportions of the different sources in the diet can be calculated through the isotopic mixing model provided that their stable isotope ratios differ sufficiently (Dunton \& Schell 1987, Gleason \& Wellington 1988). 
The aim of this study was to investigate the role of the dominant local primary producers in a salt marsh (i.e. Spartina anglica and benthic diatoms) as a food source for the main benthic invertebrates through the use of $\delta^{13} \mathrm{C}$ and $\delta^{15} \mathrm{~N}$. In addition, on the basis of this data set this study addresses the question of whether isotopic mixing models can be used to estimate the proportions of food sources in the diet of benthic invertebrates.

Material and methods. Sample collection and preparation: Aiguillon Bay is centrally located on the Atlantic coast of France and contains an intertidal muddy salt marsh of about $50 \mathrm{~km}^{2}$. Filter-feeding bivalves are the main component of the animal biomass in this bay, since it represents one of the largest areas for mussel culture in France (Dardignac-Corbeil \& Prou 1995). In addition to oceanic inputs, Aiguillon Bay receives freshwater mainly from the river La Sèvre Niortaise (maximum $100 \mathrm{~m}^{3} \mathrm{~s}^{-1}$ during winter). Parts of the muddy intertidal sediments support dense populations of the marine phanerogame Spartina anglica (Mahé 1994). Sampling was performed in April 1998 in a muddy salt marsh near the mouth of the river La Sèvre Niortaise, which was colonized by Spartina anglica. Water samples were collected by pumping (10 l) from about $20 \mathrm{~cm}$ below the water surface at the sampling site. POM for isotope analysis was collected by filtration on precombusted Whatman GF/F filters within $2 \mathrm{~h}$ after collection. Subsequently, the filters were acidified $(10 \% \mathrm{HCl})$ in order to remove carbonates, quickly rinsed with distilled water and then lyophilized. At low tide, sediment samples were taken in the salt marsh by scraping the upper $1 \mathrm{~cm}$ of mud over a total surface area of approximately $1 \mathrm{~m}^{2}$. In the laboratory, sediment was freeze-dried and ground to powder using a pestle and mortar. Freeze-dried sediment samples were analysed for organic carbon and nitrogen stable isotopes after acidification according to the procedure of Nieuwenhuize et al. (1994).

At low tide, live and dead leaves and twigs of Spartina anglica were collected by hand. We also collected the phanerogame Plantago maritima in the salt marsh and the bladder wrack Fucus vesiculosus on artificial rocks bordering the marsh. These samples were cleaned of their epibionts, washed with $10 \% \mathrm{HCl}$ to remove carbonates and rinsed with distilled water. Subsequently, the samples were freeze-dried and ground to powder using a pestle and mortar.

Spartina anglica and mats of benthic diatoms were common in the salt marsh. Benthic diatoms were collected in the marsh at low tide by scraping the surface of the sediment and extracted according to a method slightly modified from that of Couch (1989). The sediment containing the diatoms was put into flat trays to form a $1 \mathrm{~cm}$ thick layer. A nylon screen (63 $\mu \mathrm{m}$ mesh) was put on top of the sediment and this was covered with a $5 \mathrm{~mm}$ thick layer of combusted silica powder (60 to $210 \mu \mathrm{m})$. The trays were illuminated for 1 to $3 \mathrm{~h}$, until the first dense brown mats appeared at the surface (usually 0.5 to $2 \mathrm{~h}$ ). Meanwhile, the silica powder was kept moist by spraying filtered (GF/F) seawater from the sampling site. The top $2 \mathrm{~mm}$ of the silica powder was removed, and sieved over a $63 \mu \mathrm{m}$ mesh nylon screen in order to separate the diatoms from the remaining silica powder and nematodes or copepods. The diatoms were then collected on precombusted $\mathrm{GF} / \mathrm{F}$ filters, washed with $10 \% \mathrm{HCl}$, quickly rinsed with distilled water and subsequently freezedried.

The tellinacean bivalves Macoma balthica and Scrobicularia plana and the green crab Carcinus maenas were collected in the salt marsh at low tide. The blue mussel Mytilus edulis was collected on the artificial rocks bordering the marsh. In the laboratory all individuals were cleaned of epibionts and incubated overnight in filtered seawater from the sampling site to allow evacuation of gut contents. The specimens were then killed by freezing. After dissection from the shell (molluscs) or from the entire cuticle (crabs), the tissue was acidified $(10 \% \mathrm{HCl})$ to remove any carbonate debris and rinsed with distilled water. The material was subsequently freeze-dried and ground to powder using a pestle and mortar.

Nematodes were collected in the salt marsh at low tide by scraping the upper $2 \mathrm{~cm}$ of muddy sediments where most of the meiofauna (i.e. harpacticoids and nematodes) occurred (Coull \& Bell 1979). Nematodes were extracted from 31 of sediment. In the laboratory, meiofauna was concentrated by sieving the sediment cautiously through a $500 \mu \mathrm{m}$ sieve and subsequently through a $125 \mu \mathrm{m}$ sieve in order to remove macrofauna, large particles, and to decrease the sample volume (Couch 1988). The fraction retained on the $125 \mu \mathrm{m}$ sieve was used for the extraction of nematodes. Nematodes were isolated due to their negative phototropism, following the procedure of Couch (1988), modified by Riera et al. (1996). Although this method did not give a quantitative extraction of all nematodes, it did not require the use of chemicals that could interfere with the analyses. Following extraction, the nematodes were starved for $12 \mathrm{~h}$ in $0.7 \mu \mathrm{m}$ filtered seawater, during which time the gut contents were cleared, and then rinsed cautiously prior to further removal of any remaining contaminants, which was done manually, using a dissecting microscope. Nematodes were finally collected on precombusted Whatman GF/F filters $(80$ to 100 pooled individuals), briefly rinsed with distilled water and kept frozen until analysis.

Stable isotope analysis: Carbon and nitrogen isotope ratios were determined using a Fisons $\mathrm{CN}$ analyser 
Table 1. Carbon and nitrogen stable isotope ratios (mean $\pm \mathrm{SD}$ ) for SOM, POM, primary producers and benthic invertebrates in Aiguillon Bay, France. $n$ : number of analysed samples

\begin{tabular}{|lcrr|}
\hline Sample & $\mathrm{n}$ & $\delta^{13} \mathrm{C}(\%)$ & $\delta^{15} \mathrm{~N}(\%)$ \\
\hline Organic matter sources & & & \\
SOM & 3 & $-20.6 \pm 0.5$ & $6.4 \pm 0.4$ \\
Suspended POM & 3 & $-22.4 \pm 0.0$ & $5.0 \pm 1.2$ \\
Benthic diatoms & 4 & $-14.4 \pm 0.2$ & $4.5 \pm 0.3$ \\
Living Spartina anglica & 3 & $-13.5 \pm 0.2$ & $4.4 \pm 0.0$ \\
Detrial Spartina anglica & 3 & $-14.2 \pm 0.2$ & $6.4 \pm 0.0$ \\
Plantago maritima & 3 & $-24.9 \pm 0.1$ & $9.4 \pm 0.0$ \\
Fucus vesiculosus & 3 & $-19.6 \pm 0.1$ & $5.7 \pm 0.0$ \\
& & & \\
Bentic invertebrates & & & \\
Nematodes & 7 & $-16.2 \pm 1.7$ & $7.5 \pm 1.1$ \\
Mytilus edulis & 5 & $-17.4 \pm 0.2$ & $9.4 \pm 0.4$ \\
Macoma balthica & 5 & $-14.9 \pm 0.7$ & $8.5 \pm 0.2$ \\
Scrobicularia plana & 2 & $-15.6 \pm 0.4$ & $9.0 \pm 0.3$ \\
Carcinus maenas & 2 & $-14.3 \pm 0.0$ & $10.4 \pm 1.2$ \\
\hline
\end{tabular}

contribution of allochthonous sources to the SOM pool, while the isotopic composition of the suspended POM seemed to be more influenced by terrestrial organic matter (Fig. 1).

Mean $\delta^{13} \mathrm{C}$ values of $-14.4 \pm 0.2,-13.5 \pm 0.2$ and $-14.2 \pm 0.2 \%$ were measured for benthic diatoms and live and detrital Spartina anglica, respectively. The $\delta^{13} \mathrm{C}$ for benthic diatoms were close to the $\delta^{13} \mathrm{C}$ reported for benthic diatoms in mudflats of MarennesOléron Bay, France (Riera et al. 1996). The $\delta^{15} \mathrm{~N}$ for benthic diatoms $\left(4.5 \pm 0.3 \%\right.$ ) were comparable to $\delta^{15} \mathrm{~N}$ values of benthic diatoms inhabiting mudflats of Marennes-Oléron Bay, France (4.1 to $6.9 \%$ ) (Riera 1998), but less depleted than the $3.9 \%$ reported by Couch (1989) for benthic diatoms in a salt marsh of the North Inlet Estuary (South Carolina). A mean $\delta^{15} \mathrm{~N}$ value of $6.4 \pm 0.05 \%$ was measured in detrital coupled, via a Finnigan con-flo 2 interface, to a Finnigan Delta $S$ massspectrometer.

Data are expressed in the standard $\delta$ unit notation where

$$
\delta \mathrm{X}=\left[\left(R_{\text {sample }} / R_{\text {reference }}\right)-1\right] \times 10^{3}
$$

where $R={ }^{13} \mathrm{C} /{ }^{12} \mathrm{C}$ for carbon and ${ }^{15} \mathrm{~N} /{ }^{14} \mathrm{~N}$ for nitrogen, and reported relative to the Vienna Pee Dee Belemnite standard (PDB) for carbon and to air $\mathrm{N}_{2}$ for nitrogen. Average reproducibilities based on replicate measurements for $\delta^{13} \mathrm{C}$ and $\delta^{15} \mathrm{~N}$ were about 0.1 and $0.13 \%$, respectively.

Results and discussion. Isotopic characterisation of SOM, POM and potential organic matter sources for invertebrates: $\delta^{13} \mathrm{C}$ and $\delta^{15} \mathrm{~N}$ values (mean $\pm \mathrm{SD}$ ) for suspended POM, sedimented organic matter (SOM), primary producers and benthic invertebrates are summarized in Table 1. POM $\delta^{15} \mathrm{~N}$ was $5.0 \pm 1.2 \%$, close to $\delta^{15} \mathrm{~N}$ of $5.9 \%$ for estuarine POM reported for the Tay estuary (Thornton \& Mc Manus 1994). SOM $\delta^{15} \mathrm{~N}$ was 6.4 $\pm 0.4 \%$, similar to $\delta^{15} \mathrm{~N}$ values reported previously for other coastal intertidal sediments (Couch 1989, Owens \& Law 1989, Riera et al. 1996). In the dual isotope plot, marsh SOM is found in the area in which it was predicted to be when it is derived from the main local primary producers. This indicated little

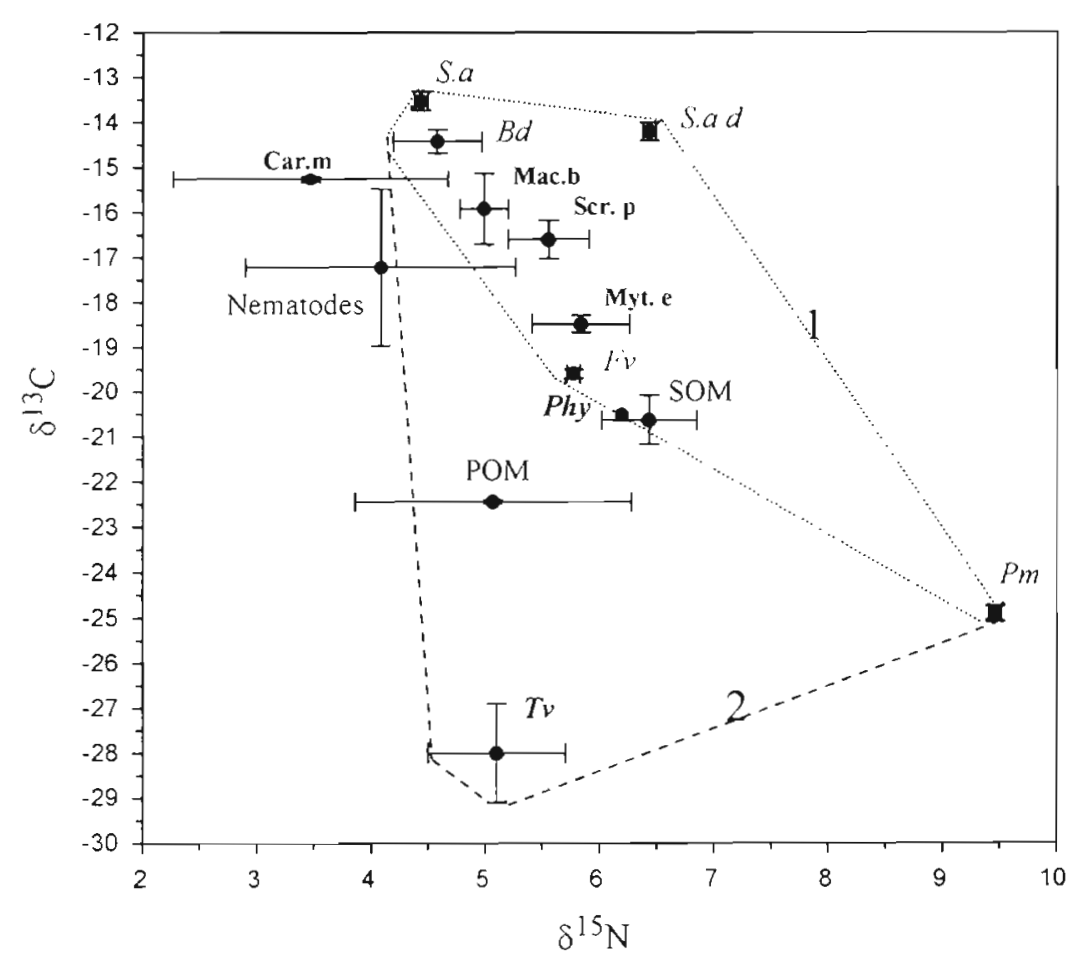

Fig. 1. $\delta^{13} \mathrm{C}$ versus $\delta^{15} \mathrm{~N}$ of benthic invertebrates corrected for trophic fractionation, compared to $\delta^{13} \mathrm{C}$ and $\delta^{15} \mathrm{~N}$ of POM, SOM and the main organic matter sources in Aiguillon Bay. Primary producers: $S a=S$. anglica, $S a d=$ detrital Spartina anglica, $B d=$ benthic diatoms, $P m=$ Plantago maritima, $T V=$ terrestrial vegetation; $P$ hy $=$ phytoplankton. Primary consumers: Nematodes, Myt.e = Mytilus edulis, Mac.b = Macoma balthica, Scr.p = Scrobicularia plana. Secondary consumer: Car $\mathrm{m}=$ Carcinus maenas. 1 and $3.5 \%$ were subtracted from the $\delta^{13} \mathrm{C}$ and $\delta^{15} \mathrm{~N}$ values respectively of primary consumers to correct for trophic fractionation. 2 and $7 \%$ were subtracted from the $\delta^{13} \mathrm{C}$ and $\delta^{15} \mathrm{~N}$ values respectively of Carcinus maenas. Dashed lines encompass the areas where isotopic values for consumers (corrected for trophic fractionation) are expected when their feeding consists of a mix of the main primary producers locally produced alone (1) or including allochthonous sources (2) 
$S$. anglica, which was higher than the $\delta^{15} \mathrm{~N}$ of the corresponding living plant $(4.4 \pm 0.05 \%)$ and the $\delta^{15} \mathrm{~N}$ of $2.5 \%$ reported for detrital $S$. alterniflora (see Currin et al. 1995 for a review). The $\delta^{15} \mathrm{~N}$ for Fucus vesiculosus was slightly lower with $5.7 \pm 0.05 \%$ than the $\delta^{15} \mathrm{~N}$ of $8.1 \%$ reported by Mayer et al. (1988). In comparison with other primary producers, Plantago maritima showed a higher $\delta^{15} \mathrm{~N}$ of $9.4 \%$ and a lower $\delta^{13} \mathrm{C}$ of $-24.9 \pm 0.1 \%$, which indicated the presence of the C3 pathway of photosynthesis (Fry \& Sherr 1984). In this study, the main sources of organic matter had reasonably distinct $\delta^{13} \mathrm{C}$ and $\delta^{15} \mathrm{~N}$ values, which allowed their use to imply food sources for the invertebrates considered. Particularly, a large difference in $\delta^{15} \mathrm{~N}$ was observed between live and dead $S$, anglica while $\delta^{13} \mathrm{C}$ values were similar. Previous studies reported that $\delta^{15} \mathrm{~N}$ for detritus derived from S. alterniflora resulted largely from nitrogen sequestered from the environment by bacteria as well as from adsorbed external nitrogenous compounds (Couch 1989, Currin et al. 1995). Variation in $\delta^{15} \mathrm{~N}$ in detrital $S$. anglica might have been due to the uptake of external nitrogen by bacteria associated with $S$. anglica detritus (Rice 1982, Whites \& Howes 1994).

Nematodes revealed a $\delta^{13} \mathrm{C}$ value of $-16.2 \pm 1.7 \%$, similar to the $\delta^{13} \mathrm{C}$ reported from Marennes-Oléron Bay (Riera et al. 1996). The corresponding $\delta^{15} \mathrm{~N}(7.5 \pm$ $1.1 \%$ ) was in between the $\delta^{15} \mathrm{~N}$ of $9.1 \%$ observed in Marennes-Oléron Bay and the $\delta^{15} \mathrm{~N}$ of $5.3 \%$ for nematodes in a Spartina salt marsh in the United States (Couch 1989). The $\delta^{15} \mathrm{~N}$ values of bivalves increased from Macoma balthica $(8.5 \pm 0.2 \%)$ via Scrobicularia plana $(9.0 \pm 0.3 \%)$ to Mytilus edulis $(9.4 \pm 0.4 \%$ ). The corresponding $\delta^{13} \mathrm{C}$ decreased from $M$. balthica $(-14.9$ $\pm 0.7 \%$ ) , via S. plana $(-15.6 \pm 0.4 \%)$ to $M$. edulis $(-17.4$ $\pm 0.2 \%$. Carcinus maenas had the highest values of $\delta^{15} \mathrm{~N}(10.4 \pm 1.2 \%)$ and $\delta^{13} \mathrm{C}(-14.3 \pm 0.0 \%$, which suggested a more carnivorous mode of life for this species.

The identification of food sources for benthic consumers (Fig. 1) considered: (1) a mean trophic enrichment in ${ }^{13} \mathrm{C}$ of $1 \%$ (DeNiro \& Epstein 1978, Rau et al. 1983 ) and a mean trophic enrichment in ${ }^{15} \mathrm{~N}$ of $3.5 \%$ (Minagawa \& Wada 1984, Owens 1987) as a result of the assimilation of food, and (2) sources of organic matter locally produced and allochthonous sources. The main allochthonous food sources in the bay were terrestrial organic matter carried by the Sevvre Niortaise River and marine phytoplankton that entered the Aiguillon Bay through tidal currents. The most common terrestrial plants in the meadows and forests of the drainage basin of the Charente River were C3 plants and these had a mean $\delta^{13} \mathrm{C}$ of $-28 \pm 1.1 \%$ and $\delta^{15} \mathrm{~N}$ of $5.1 \pm 0.6 \%$ (Riera \& Richard 1996, Riera 1998). Recently, Fogel \& Cifuentes (1993) reported a similar mean $\delta^{i 5} \mathrm{~N}$ of $4 \%$ for terrestrial plants. Isotopic values for marine phytoplankton were not measured in this study. However, Richard et al. (1997) measured a $\delta^{13} \mathrm{C}$ of $-20.6 \%$ off Marennes-Oléron Bay close to the oceanic entrance of the Aiguillon Bay. Miyake \& Wada (1967) and Wainright et al. (1998) reported $\delta^{15} \mathrm{~N}$ values for marine phytoplankton of $6 \%$ and of 6.6 to $6.7 \%$, respectively.

Food sources of Macoma balthica, Scrobicularia plana and Mytilus edulis: A continuum of $\delta^{13} \mathrm{C}$ versus $\delta^{15} \mathrm{~N}$ values was found, starting with $M$. balthica via $S$. plana to $M$. edulis (Fig. 1). In this study, the contribution of ${ }^{13} \mathrm{C}$-enriched sources of organic matter (i.e. benthic diatoms and live and dead $S$. anglical to the benthic food web could not be distinguished by using the $\delta^{13} \mathrm{C}$ values. The invertebrates might have used detrital organic matter derived from Spartina anglica as a food source. In fact, microbially mediated processes occurring during decomposition of eelgrass result in the production of detritus and associated bacteria, which are more nutritious and readily usable (Tenore et al. 1982). Experimental studies have shown that trophic mediation between vascular plants and bivalves can occur through bacteria associated with the decay of detrital refractory material (Crosby et al. 1990, Langdon \& Newell 1990). Similarly, a bacterial trophic mediation has been hypothesised to explain the use of organic matter of terrestrial origin by oysters (Riera 1998). In the present study, $\delta^{15} \mathrm{~N}$ discriminated between live and dead $S$ anglica (Fig. 1), and these data suggested that detrital organic matter derived from this plant did not make an important contribution to the diet of these invertebrates.

However, benthic diatoms alone could not fully explain the isotopic composition of the invertebrates considered. It was unlikely that Plantago maritima and Fucus vesiculosus contributed significantly to the feeding of the invertebrates because they are not important as primary producers in this part of Aiguillon Bay compared with Spartina anglica (Riera pers. obs.). Moreover, although this marsh is directly influenced by river inputs, $\delta^{13} \mathrm{C}$ versus $\delta^{15} \mathrm{~N}$ indicated that terrestrial organic matter was also not incorporated into the tissues of the invertebrates (Fig. 1). In fact, $\delta^{13} \mathrm{C}$ and $\delta^{15} \mathrm{~N}$ of Macoma balthica, Scrobicularia plana and Mytilus edulis could be mainly explained by a mixed diet of benthic diatoms and marine phytoplankton. This result is consistent with the hypothesis that living microalgae such as benthic diatoms and phytoplankton are easier to use and more nutritious for marine bivalves than detritus of vascular plants (Bayne et al. 1987, Crosby et al. 1989),

Use of isotopic mixing model: The quantitative proportion of the main food sources incorporated by consumers was based on a mixing model using $\delta^{13} \mathrm{C}$ values. In fact, $\delta^{15} \mathrm{~N}$ is not as powerful as $\delta^{13} \mathrm{C}$ in the 
discrimination of food sources, because of the lower ranges of $\delta^{15} \mathrm{~N}$ values and overlapping of values for food sources and invertebrates, as shown previously in coastal ecosystems (Fry \& Sherr 1984, Couch 1989). The model assumed a proportional assimilation of food and that the $\delta^{13} \mathrm{C}$ value becomes $1 \%$ less in the diet (De Niro \& Epstein 1978). The proportion of carbon assimilated by invertebrates from benthic diatoms and phytoplankton can be calculated using the equation:

$$
\begin{gathered}
\delta^{13} \mathrm{C}_{\text {anımal }}=P_{\mathrm{b}} \delta^{13} \mathrm{C}_{\mathrm{b}}+P_{\mathrm{p}} \delta^{13} \mathrm{C}_{\mathrm{p}} \\
\text { with } P_{\mathrm{b}}+P_{\mathrm{p}}=1
\end{gathered}
$$

where $P$ is the proportion of benthic diatoms (b) and phytoplankton (p) that contribute to animal diet. To solve for $P_{\mathrm{b}}$ and $P_{\mathrm{p}}$ the mean carbon isotope values for benthic diatoms and phytoplankton were fractionated by $1 \%$.

The results indicated that Macoma balthica was preferentially a deposit feeder because this bivalve used a higher proportion of benthic diatoms (75.8\%) compared to marine phytoplankton (24.2\%). Scrobicularia plana also preferentially used benthic diatoms $(64.5 \%)$, but behaved slightly more like suspension feeders, using a higher proportion of phytoplankton $(35.5 \%)$. These values confirmed the suspensiondeposit-feeding mode previously observed in feeding behaviour studies of $M$. balthica (Hummel 1985) and S. plana (Hughes 1969). However, this study suggests a slight difference in feeding modes between the 2 bivalves, although they were from the same habitat. The isotopic position of Mytilus edulis suggested that this suspensivore subsists primarily on phytoplankton $(64.6 \%)$ but also consistently uses benthic diatoms $(35.4 \%)$.

The examination of $\delta^{13} \mathrm{C}$ and $\delta^{15} \mathrm{~N}$ in this salt marsh showed that the diet of benthic consumers was not necessarily dependent on the dominant primary producers to which they were exposed. In fact, although Spartina anglica was largely available to the benthic invertebrates through detrital organic matter, other primary producers, autochthonous or allochthonous, which were more readily consumable (i.e. living microphytes) were preferentially used as food sources.

Food sources of nematodes and Carcinus maenas: The $\delta^{13} \mathrm{C}$ versus $\delta^{15} \mathrm{~N}$ for nematodes and C. maenas did not match the values that would have been expected when their feeding consisted of a mix of the main sources to which they were exposed (Fig. 1). Although $\delta^{13} \mathrm{C}$ and $\delta^{15} \mathrm{~N}$ suggested that benthic diatoms were part of the food of the nematodes, their contribution was less important than previously observed in the mudflat of Marennes-Oléron Bay. In this mudflat, benthic diatoms represented the main food source ingested (Montagna et al. 1995) and assimilated over a sampling year (Riera et al. 1996) by nematodes. However, in Marennes-Oléron Bay vascular plants like Spartina are virtually absent. These results support the suggestion made by Couch (1989) that microphytobenthos cannot constitute the sole food source of nematodes in a $S$. anglica salt marsh. Meiobenthic fauna mainly consists of grazers, adapted to ingest microbial food items such as microalgae, bacteria and protozoa (Montagna 1995). Particularly, in detritus-based food webs, bacteria often appear to constitute the main food source for meiofauna (Gerlach 1978). In the salt marsh of Aiguillon Bay, large ranges in $\delta^{13} \mathrm{C}$ and $\delta^{15} \mathrm{~N}$ of nematodes suggest a high diversity of food sources. This diversity could be explained assuming a nematode community which consists of a mixture of species from different feeding guilds (i.e. algivores, bactivores and predators). This would be consistent with the classification of Weiser (1953). According to this hypothesis, the heterogeneity of feeding modes of different nematode species at different trophic levels would imply that the trophic enrichments (i.e. $1 \%$ for carbon. and $3.5 \%$ for nitrogen) as shown in Fig. 1 are not valid for the whole nematode community. This result is consistent with the suggestion made by Bongers \& Ferris (1999) that, when functional divergence within a nematode community occurs, identification to genus or species level should be necessary.

Furthermore, Carcinus maenas exhibited a high variability in $\delta^{15} \mathrm{~N}$, which could be explained by a high diversity of food sources and/or different trophic levels for the individuals considered. This result is in agreement with the omnivory feeding mode of $C$. maenas, which was evidenced by the patterns of digestive enzymes in the larvae (Kumlu \& Jones 1997).

The $\delta^{13} \mathrm{C}$ and $\delta^{15} \mathrm{~N}$ values measured in this salt marsh suggest complex trophic relationships for nematodes and Carcinus maenas. This did not allow the use of trophic enrichment coefficients and the use of isotopic mixing models to accurately estimate the proportional contributions of the main food sources for these invertebrates.

Acknowledgements. This work was supported by the European Commission in the MAST programme, contract MAS3CT97-5039 and part of the project INTRMUD (MAS3-CT950022). We would like to thank Yvonne Maas for analytical assistance. The comments of 4 anonymous reviewers also greatly contributed to improving the manuscript. This is publication 2582 of NIOO-CEMO.

\section{LITERATURE CITED}

Bayne BL, Hawkins AJS, Navarro E (1987) Feeding and digestion by the mussel Mytilus edulis L. (Bivalvia: Mollusca) in mixtures of silt and algal cells at low concentrations. J Exp Mar Biol Ecol 111:1-22 
Bongers T, Ferris H (1999) Nematode community structure as a bioindicator in environmental monitoring. Trends Ecol Evol 14:224-228

Coull BC, Bell SS (1979) Perspectives in meiofaunal ecology In: Livingston RJ (ed) Ecological processes in coastal and marine systems. Plenum Press, New York, p 189-216

Couch CA (1988) A procedure for extracting large numbers of debris-free, living nematodes from muddy marine sediments. Trans Am Microsc Soc 107:96-100

Couch CA (1989) Carbon and nitrogen stable isotopes of meiobenthos and their food resources. Estuar Coast Shelf Sci 28:433-441

Crosby MP, Langdon CJ, Newell RIE (1989) Importance of refractory plant material to the carbon budget of the oyster Crassostrea virginica. Mar Biol 100:343-352

Crosby MP, Newell RIE, Langdon CJ (1990) Bacterial mediation in the utilization of carbon and nitrogen from detrital complexes by Crassostrea virginica. Limnol Oceanogr 35: $625-639$

Currin CA, Newell SY, Paerl HW (1995) The role of standing dead Spartind alterniflora and benthic microalgae in salt marsh food webs: considerations based on multiple stable isotope analysis. Mar Ecol Prog Ser 121:99-116

Dardignac-Corbeil MJ, Prou J (1995) À propos des problèmes de captage de naissain de moules (Mytilus edulis L.) dans le Pertuis Breton de 1989 à 1991: observations préliminaires. Haliotis 24:13-312

Deegan LA, Garritt RH (1997) Evidence for spatial variability in estuarine food webs. Mar Ecol Prog Ser 147:31-47

Deegan LA, Peterson BJ, Portier R (1990) Stable isotopes and cellulase activity as evidence for detritus as a food source for juvenile Gulf menhaden. Estuaries 13:14-19

DeNiro MJ, Epstein S (1978) Influence of diet on the distribution of carbone isotopes in animals. Geochim Cosmochim Acta 42:495-506

Dunton KH, Schell DM (1987) Dependence of consumers on macroalgal (Laminaria solidungula) carbon in an arctic kelp community: $\delta^{13} \mathrm{C}$ evidence. Mar Biol 93:615-625

Fogel ML, Cifuentes LA (1993) Isotope fractionation during primary production. In: Engel MH, Macko SA (eds) Organic geochemistry: principles and applications. Plenum Press, New York, p 73-98

Fry B, Sherr EB (1984) $\delta^{13} \mathrm{C}$ measurements as indicators of carbon flow in marine and freshwater ecosystems. Contrib Mar Sci 27:13-47

Gerlach SA (1978) Food-chain relationships in a subtidal silty sand marine sediments and the role of meiofauna in stimulating bacterial productivity. Oecologia 33:55-69

Gleason DF, Wellington GM (1988) Food resources of postlarval brown shrimp (Penaeus aztecus) in a Texas salt marsh. Mar Biol 97:329-337

Hughes RN (1969) A study of feeding in Scrobicularia plana. J Mar Biol Assoc UK 49:805-823

Hummel H (1985) Food intake of Macoma balthica (Mollusca) in relation to seasonal changes in its potential food on a tidal flat in the Dutch Wadden Sea. Neth J Sea Res 19: $52-76$

Incze LS, Mayer LM, Sherr EB, Macko SA (1982) Carbon inputs to bivalve mollusks: a comparison of two estuaries. Can J Fish Aquat Sci 39:1348-1352

Kumlu M, Jones DA (1997) Digestive protease activity in planktonic crustaceans feeding at different trophic level. J Mar Biol Assoc UK 77:159-165

Langdon CJ, Newell RIE (1990) Utilization of detritus and bacteria as food sources by two bivalve suspensionfeeders, the oyster Crassostrea virginica and the mussel Geukensia demissa. Mar Ecol Prog Ser 58:299-310
Mahé JL (1994) Moules et mytiliculture en baie de l'Aiguillon Rumeurs des Ages, La Rochelle

Mann KH (1988) Production and use of detritus in various freshwater, estuarine, and coastal marine ecosystems Limnol Oceanogr 33:910-930

Mayer LM, Macko SA, Cammen L (1988) Provenance, concentrations and nature of sedimentary organic nitrogen in the Gulf of Maine. Mar Chem 25:291-304

Minagawa M, Wada E (1984) Stepwise enrichment of ${ }^{15} \mathrm{~N}$ along food chains: further evidence and the relation between $\delta^{15} \mathrm{~N}$ and animal age. Geochim Cosmochim Acta 48:1135-1140

Miyake Y, Wada E (1967) The abundance ratios of ${ }^{15} \mathrm{~N} /{ }^{14} \mathrm{~N}$ in marine environments. Rec Oceanogr Works Jpn 9: $37-53$

Monbet Y (1992) Control of phytoplankton biomass in estuaries - a comparative analysis of microtidal and macrotidal estuaries. Estuaries 15:563-571

Montagna PA (1995) Rates of metazoan meiofaunal microbivory: a review. Vie Milieu 45:1-19

Montagna PA, Blanchard GF, Dinet A (1995) Effect of production and biomass of intertidal microphytobenthos on meiofaunal grazing rates. J Exp Mar Biol Ecol 185 $149-165$

Nieuwenhuize J, Mass YEM, Middelburg JJ (1994) Rapid analysis of organic carbon and nitrogen in particulate materials. Mar Chem 45:217-224

Newell RIE, Langdon CJ (1986) Digestion and absorption of refractory carbon from the plant Spartina alterniflora (Loisel) by the oyster Crassostrea virginica (Gmelin). Mar Ecol Prog Ser 34:105-115

Owens NJP (1987) Natural variations in ${ }^{15} \mathrm{~N}$ in the marine environment. In: Blaxter JHS, Southward AJ (eds) Advances in marine biology, Vol 24. Academic Press, London, p 389-451

Owens NJP, Law CS (1989) Natural variations in ${ }^{15} \mathrm{~N}$ content of riverine and estuarine sediments. Estuar Coast Shelf Sci 28:407-416

Pocklington $\mathrm{R}$, Tan FC (1987) Seasonal and annual variations in the organic matter contributed by the St. Lawrence River to the Gulf of St. Lawrence. Geochim Cosmochim Acta 51:2579-2586

Rau GH, Mearns A.J, Young DR, Olson RJ, Schafer HA, Kaplan IR (1983) Animal ${ }^{13} \mathrm{C}^{12} \mathrm{C}$ correlates with trophic level in pelagic food webs. Ecology 64:1314-1318

Rice DL (1982) The detritus nitrogen problem. New observations and perspectives from organic geochemistry. Mar Ecol Prog Ser 9:153-162

Richard P, Riera P, Galois R (1997) Temporal variations in the chemical and carbon isotope compositions of maxine and terrestrial organic inputs in the Bay of Marennes-Oléron (France). J Coastal Res 13:879-889

Riera P (1998) $\delta^{15} \mathrm{~N}$ of organic matter sources and benthic invertebrates along an estuarine gradient in $\mathrm{Ma}$ rennes-Oléron Bay (France): implications for the study of the trophic structure. Mar Ecol Prog Ser 166 $143-150$

Riera P, Richard P (1996) Isotopic determination of food sources of Crassostrea gigas along a trophic gradient in the estuarine bay of Marennes-Oléron. Estuar Coast Shelf Sci 42:347-360

Riera P, Richard P, Grémare A, Blanchard G (1996) Food source of intertidal nematodes in the Bay of MarennesOléron (France), as determined by dual isotope analysis. Mar Ecol Prog Ser 142:303-309

Schwinghamer P, Tan FC, Gordon DC (1983) Stable carbon isotope studies on the pecks cove mudflat ecosystem in the 
Cumberland basin, Bay of Fundy. Can J Fish Aquat Sci 40 (Suppl 1):262-273

Tenore KR (1983) What controls the availability to animals of detritus derived from vascular plants:organic nitrogen, enrichment or caloric availability. Mar Ecol Prog Ser 10:307-309

Tenore KR, Cammen L, Findlay SEG, Phillips N (1982) Perspectives of research on detritus: do factors controlling the availability of detritus to macroconsumers depend on its source? J Mar Res 40:473-490

Thornton SF, Mc Manus J (1994) Application of organic carbon and nitrogen stable isotope and $\mathrm{C} / \mathrm{N}$ ratios as source indicators of organic matter provenance in estuarine sys-

Editorial responsibility: Otto Kinne (Editor),

Oldendorf/Luhe, Germany tems-evidence from the Tay Estuary, Scotland. Estuar Coast Shelf Sci 38:219-233

Wainright SC, Haney JC, Kerr C, Golovkin AN, Flint MV (1998) Utilization of nitrogen derived from seabird guano by terrestrial and marine plants at St. Paul, Pribilof Islands, Bering Sea, Alaska. Mar Biol 131:63-71

Weiser W (1953) Die Beziehung zwischen Mundhöhlengestalt, Ernährungsweise und Vorkommen bei freilebenden. marinen Nematoden. Ark Zool 4:439-484

Whites DS, Howes BL (1994) Nitrogen incorporation into decomposing litter of Spartina alterniflora. Limnol Oceanogr 39:133-140

Submitted: March 17, 1999; Accepted: August 2, 1999 Proofs received from author(s): September 16, 1999 